очевидний висновок про необхідність вдосконалення спеціального законодавства, що регулює правовідносини у сфері банківських карт або внесення відповідних змін до вже наявного законодавства. Вважаємо, що саме такий варіант може сприяти подальшому розвитку національних платіжних систем, а також дозволить розв'язати наявні проблеми у сфері здійснення безготівкових розрахунків за допомогою банківських карт.

\title{
Література:
}

1. Цивільний кодекс України// Відомості Верховної Ради України (BBP), 2003. №№ 40-44. Ст. 356.

2. Коць О.О., Гоменюк В.В. Сучасний стан і перспективи розвитку ринку платіжних карток в Україні. Економіка і суспільство. Випуск № 15. 2018. C. 671-678. URL:http://economyandsociety.in.ua/journal/ 15_ukr/102.pdf

3. Про платіжні системи та переказ коштів в Україні:Закон України. Електронний ресурс. Режим доступу :https://zakon.rada.gov.ua/laws/show/ 2346-14\#Text

4. Беззаперечні тренди карткового ринку у 2020 році - розрахунки в Інтернеті та безконтактні платежі .Електронний ресурс .Режим доступу : https://bank.gov.ua/ua/news/all/bezzaperechni-trendi-kartkovogo-rinku-u2020-rotsi--rozrahunki-v-interneti-ta-bezkontaktni plateji\#: :text=Загальна\% 20кількість\%20емітованих\%20платіжних\%20карток,порівняти\%203\%20с ічнем\% $\% 20202 \% 20$ року*.

DOI https://doi.org/10.30525/978-9934-26-074-2-17

\section{ЕВОЛЮЦІЯ СТАНОВЛЕННЯ ЗАКОНОДАВСТВА В СФЕРІ ВИКОРИСТАННЯ ІНФОРМАЦЙННИ ТЕХНОЛОГІЙ У ЦИВІЛЬНОМУ ПРОЦЕСІ}

\author{
Маричева О. Д. \\ адвокат, \\ заступник директора юридичного департаменту \\ $T_{3} O B$ «ПЛГ «Micm Груп», \\ аспірант кафедри ичвільно-правових дисциплін \\ Інституту права \\ Львівського державного університету внутрішніх справ \\ м. Львів, Україна
}

Сучасне життя людей, його інформатизація безумовно впливають на всі сфери соціально-економічного, політичного і культурного життя 
суспільства та зумовлюють необхідність у створенні передумов для використання інформаційних технологій в судочинстві, зокрема в цивільному процесі.

Нормативно-правове та нормативно-технічне забезпечення процесу впровадження інформаційних технологій та інформатизації в Україні стартувало після прийняття у 1998 році законів України «Про Національну програму інформатизації», «Про Концепцію Національної програми інформатизації» та «Про затвердження Завдань Національної програми інформатизації на 1998-2000 роки» та низки інших нормативних актів Кабінету Міністрів України та Президента України.

Національна програма інформатизації визначила стратегію розв’язання проблеми забезпечення інформаційних потреб та інформаційної підтримки у сферах загальнодержавного значення.

Підтвердження ролі інформаційних технологій відбулося 3 прийняттям 06-07.05.1999 Радою Свропи Декларації про європейську політику в галузі нових інформаційних технологій, а Окінавська Хартія глобального інформаційного суспільства від 22.07.2000 закріпила погляд на інформаційно-комунікаційні технології як на один із найбільш важливих чинників, що впливають на формування суспільства XXI століття.

Свропейська регіональна конференція, що відбулася 07-09.11.2002 в Бухаресті, запропонувала концепцію інформаційного суспільства. Повномасштабне використання нових можливостей, що створюються інформаційними й комунікаційними технологіями повинні стати важливими компонентами будь-якої стратегії як національної, так і міжнародної, розрахованої на досягнення цілей розвитку, встановлених у Декларації тисячоліття.

Концептуальною основою для розробки завдань щодо розвитку інформаційного суспільства в Україні став Закон України «Про Основні засади розвитку інформаційного суспільства в Україні на 2007-2015 роки», який визнав інформаційний напрям державної політики одним iз пріоритетних, окреслив завдання, цілі та напрями розвитку інформаційного суспільства в Україні.

15.05.2013 Кабінетом Міністрів України схвалено Стратегії розвитку інформаційного суспільства в Україні, яка визначила мету, завдання, базові принципи та стратегічні цілі розвитку інформаційного суспільства в Україні в перспективі до 2020 року.

Беручи до уваги викладене вище, надзвичайно важливим постало питання інформатизації судової системи, оскільки без впровадження інформаційних технологій та автоматизації певних процесів в суді неможливий подальший розвиток системи правосуддя. 
Впровадження інформаційних технологій у судову систему, зокрема цивільний процес, дозволяє забезпечити удосконалення якості роботи діяльності суду, пришвидшити та полегшити роботу його працівникам, більшою мірою гарантувати належний доступ громадян до правосуддя, допомагає виконати завдання, поставлені перед цивільним судочинством, та дотриматися основних його принципів.

Для досягнення поставлених цілей, важливим було прийняття 22.05.2003 Закону України «Про електронні документи та електронний документообіг», що встановив основні організаційно-правові засади електронного документообігу та використання електронних документів, визначив поняття електронного документа та електронного документообігу, закріпив визнання юридичної сили електронних документів, визначив права, обов'язки та відповідальність суб'єктів електронного документообігу.

Крім того, було прийнято Закон України «Про електронний цифровий підпис», що окреслив правовий статус електронного цифрового підпису та регулював відносини, що виникають при використанні електронного цифрового підпису, а 05.10.2017 - Закон України «Про електронні довірчі послуги».

Важливим кроком на шляху до інформатизації судової системи стало затвердження 21.12.2012 Радою суддів України Стратегічного плану розвитку судової влади України на 2013-2015 роки, в якому одним із стратегічних завдань судової влади України визначено доступ до правосуддя, інноваційне використання технологій i вдосконалення судових процедур для підвищення та підтримки високого рівня довіри до судів.

Також 32012 року Державна судова адміністрація розпочала реалізацію пілотного проєкту з розвитку електронного судочинства. Тимчасовим регламентом обміну електронними документами між судом і учасниками судового процесу, затвердженого наказом ДСА України від 07.09.2012 № 105, визначена процедура подачі заявки про отримання процесуальних документів в електронному вигляді (у якості пілотних виступали 15 судів України).

3 метою забезпечення своєчасного отримання учасниками судового процесу, кримінального провадження судових повісток, повідомлень та інших документів під час розгляду судових справ, Наказом ДСА України від 07.11.2016 № 227 затверджено Тимчасовий регламент надсилання судом електронних документів учасникам судового процесу, кримінального провадження.

Значним досягненням свого часу стало створення Єдиного державного реєстру судових рішень, запровадження автоматизованої системи 
документообігу суду, а з викладенням процесуальних кодексів у новій редакції почала частково функціонувати Єдина судова інформаційнотелекомунікаційна система, що стало перспективою для переходу до електронного судочинства.

Спеціальними нормативними актами, якими запроваджено окремі елементи «електронного суду» в широкому розумінні, є Закон України «Про судоустрій i статус суддів», котрим на Державну судову адміністрацію України покладено обов'язок впровадження електронного суду, здійснення заходів щодо організації обміну електронними документами між судами та іншими державними органами й установами.

Законом України «Про доступ до судових рішень» запроваджено обов'язковість відкритого оприлюднення в електронній формі усіх судових рішень.

Цивільний процесуальний кодекс України та Положення про автоматизовану систему документообігу суду, затвердженого рішенням Ради суддів України від 02.04.2015, містять численні норми, котрі унормовують функціонування електронного судочинства.

В останній запропонованій редакції Положення про Єдину судову інформаційно-телекомунікаційну систему йдеться про впровадження найближчим часом лише тих модулів ССITC, які на сьогодні вже готові - «Електронний кабінет», «Електронний суд» та підсистема відеоконференцзв'язку.

Поетапне запровадження ЄСITC передбачено проєктом Закону України № 3985 «Про внесення змін до деяких законодавчих актів щодо забезпечення поетапного впровадження Сдиної судової інформаційнотелекомунікаційної системи». На думку законодавців, поетапне запровадження ССITC дасть змогу розпочати використання підсистем та модулів, які вже практично готові, не чекаючи готовності інших підсистем, розроблення яких перебуває лише на початковій стадії.

На сьогодні «Кабінет електронних сервісів» передбачає можливість: 1) оплати судового збору онлайн; 2) отримання інформація щодо стадій розгляду судових справ (на офіційному вебпорталі Судова влада України передбачена можливість користувачів порталу перегляду/пошуку/друку інформації щодо стадій розгляду судових справ); 3) отримання інформації з Єдиного державного реєстру судових рішень, який є автоматизованою системою збирання, зберігання, захисту, обліку, пошуку та надання електронних копій судових рішень; 4) надсилання учасникам судового процесу процесуальних документів електронною поштою; 5) відправки судової повістки у вигляді SMS-повідомлень; 6) отримання інформації про перебування суб'єктів підприємницької діяльності (контрагентів, боржників, поручителів і т.п.) у процедурі банкрутства. 
Таким чином, діджиталізація правосуддя сьогодні включає: автоматизацію багатьох судових процедур та спрощення інформування учасників справи; можливість проведення засідання в режимі онлайн та їхній аудіозапис; електронний документообіг (внутрішній і зовнішній); забезпечення відкритого доступу до інформації в мережі Інтернет на всіх стадіях судового процесу. Крім того, на законодавчому рівні закріплено низку нових категорій: електронне правосуддя, електронне судочинство, електронний суд або суд онлайн тощо. Введення цих понять не носить абстрактного характеру, а насамперед $є$ результатом фактичного використання новітніх технологій та їх нормативного закріплення.

DOI https://doi.org/10.30525/978-9934-26-074-2-18

\section{РОЛЬ АДВОКАТА У ВРЕГУЛЮВАННІ ПРАВОВОГО СПОРУ ЗА ДОПОМОГОЮ МЕДІАЦІЇ}

Можайкіна О. С.

кандидат психологічних наук, доцент, доцент кафедри міжнародного, иивільного та комериійного права Київського начіонального торговельно-економічного університету, адвокат

Ліщук О. В.

викладач кафедри міжнародного, цивільного та комериійного права Київського начіонального торговельно-економічного університету,

адвокат

м. Київ, Україна

Високий рівень конфліктної напруги у сучасному українському суспільстві переважно носить правовий (юридичний) характер. Традиційно фізичні та/або юридичні особи звертаються для вирішення будь-яких правових спорів до суду, де одним з основних засад процесу $є$ змагальність, що нерідко сприяє загостренню конфлікту (спору) та в кінцевому результаті може призвести до припинення правовідносин між сторонами. Існуючі проблеми судової системи нерідко призводять до значних втрат сторонами сил, часу i матеріальних ресурсів, а судове рішення, як правило, може задовольнити одну сторону спору, що в подальшому обумовлює труднощі його виконання. У зв'язку 3 цим особливо привабливим для обох сторін спору виявляється 